\title{
Nine years of UV aerosol optical depth measurements at Thessaloniki, Greece
}

\author{
S. Kazadzis ${ }^{1}$, A. Bais ${ }^{1}$, V. Amiridis ${ }^{2}$, D. Balis ${ }^{1}$, C. Meleti $^{1}$, N. Kouremeti ${ }^{1}$, C. S. Zerefos ${ }^{3}$, S. Rapsomanikis ${ }^{4}$, \\ M. Petrakakis ${ }^{5}$, A. Kelesis ${ }^{5}$, P. Tzoumaka ${ }^{5}$, and K. Kelektsoglou ${ }^{4}$ \\ ${ }^{1}$ Laboratory of Atmospheric Physics, Physics Department, Aristotle University of Thessaloniki, University Campus Box 149, \\ 54124, Thessaloniki, Greece \\ ${ }^{2}$ Institute for Space Applications and Remote Sensing, National Observatory of Athens, Athens, Greece \\ ${ }^{3}$ Univ Athens, Fac. Geol \& Geoenvironment, Climatology Lab, Athens, Greece \\ ${ }^{4}$ Democritus Univ Thrace, Department of Environmental Engnineering, Xanthi, Greece \\ ${ }^{5}$ Municipal Thessaloniki, Department of Environment, Thessaloniki, Greece
}

Received: 31 October 2006 - Published in Atmos. Chem. Phys. Discuss.: 15 January 2007

Revised: 13 March 2007 - Accepted: 17 April 2007 - Published: 26 April 2007

\begin{abstract}
Spectral measurements of the aerosol optical depth (AOD) and the Ångström coefficient were conducted at Thessaloniki, Greece $\left(40.5^{\circ} \mathrm{N}, 22.9^{\circ} \mathrm{E}\right)$ between January 1997 and December 2005 with a Brewer MKIII doublemonochromator spectroradiometer. The dataset was compared with collocated measurements of a second spectroradiometer (Brewer MKII) and a CIMEL sun-photometer, showing correlations of 0.93 and 0.98 , respectively. A seasonal variation of the AOD was observed at Thessaloniki, with AOD values at $340 \mathrm{~nm}$ of 0.52 and 0.28 for August and December respectively. Back trajectories of air masses for up to 4 days were used to assess the influence of long-range transport from various regions to the aerosol load over Thessaloniki. It is shown that part of the observed seasonality can be attributed to air masses with high AOD originating from North-Eastern and Eastern directions during summertime. The analysis of the long-term record (9 years) of AOD showed a downward tendency. A similar decreasing tendency was found in the record of the $\mathrm{PM}_{10}$ aerosol measurements, which are conducted near the surface at 4 air-quality monitoring stations in the area of the city of Thessaloniki.
\end{abstract}

\section{Introduction}

Aerosols play a very important role for the Earth-atmosphere energy budget as they modify it through various atmospheric processes. Such processes are: The direct effect by scatter-

Correspondence to: S. Kazadzis

(skazan@auth.gr) ing and absorption of the solar and earth's radiation (Coakley et al., 1983; Charlson et al., 1992), the semi-direct effect by changing atmospheric thermodynamics and cloud formation (Ackerman et al., 2000; Koren et al., 2004), and finally the indirect effect by changing cloud microphysics (Twomey, 1977; Rosenfeld and Lensky, 1998). The impact of aerosols to the planet's radiative forcing is a major component of global and regional climatic patterns, influencing processes in the atmospheric boundary layer (Yu et al., 2002), the hydrological cycle (Ramanathan et al., 2001), and surface temperatures over the globe (Charlson et al., 1992). The cooling by anthropogenic aerosols may be comparable in magnitude to greenhouse gas warming on a global scale but can be much larger on a regional scale (Intergovernmental Panel on Climate Change (IPCC), 2001). However, uncertainties remain substantial for the direct and for the indirect effect (IPCC, 2001; Anderson et al., 2003).

Aerosols found over the Mediterranean originate from various sources, such as the superimposition of a marine component, a mineral dust component (Saharan dust outbreaks and local dust suspension) and the local and long range transported anthropogenic component (Lelieveld et al., 2002; Moulin et al., 1997; di Sarra et al., 2003). In the last decade, a substantial number of experimental studies on aerosols has been focused on the eastern Mediterranean area (Luria et al., 1996; Pinker et al., 1997; Mihalopoulos et al., 1997; Papayannis et al., 1998, 2005; Formenti et al., 2001, 2002; Lelieveld et al., 2002; Gerasopoulos et al., 2003; Balis et al., 2003, 2004; Amiridis et al., 2005). Various model studies predicted maximum net direct radiative forcing by sulfate aerosols for this region (Charlson et al., 1991; Kiehl and

Published by Copernicus GmbH on behalf of the European Geosciences Union. 
Rodhe, 1995; Boucher and Anderson, 1995). For the eastern part of Mediterranean, the Aegean Sea and the coastal part of continental Greece, aerosols from different sources can be identified. Apart from local pollution, aerosols that originate from biomass burning, anthropogenic aerosols from the highly populated urban centres and industrial areas of Central and Eastern Europe and maritime aerosols, converge over this area (Formenti et al., 2002; Balis et al., 2003). For the lower troposphere over the Mediterranean, particularly during summer, European pollution is mainly responsible for the reduction of air quality, whereas in the free troposphere pollution is largely determined by trans-boundary and possibly intercontinental transport (Zerefos et al., 2000; Lelieveld et al., 2002; Balis et al., 2003, 2004).

In this paper we discuss the variability of aerosol optical depth measured with a Brewer spectroradiometer at Thessaloniki, Greece during the period January 1997 to December 2005. In Sect. 2 we describe the instrumentation and the methods used for the data analysis. Sections 3 to 5 present a statistical analysis of the Brewer-derived measurements of the aerosol optical depth in the UV region and the Ångström coefficient, along with discussions on their seasonal dependence. Back-trajectory analyses show an additional dependence of the aerosol optical depth on the origin of the air masses. In Sect. 5.2 $\mathrm{PM}_{10}$ aerosol measurements are analysed for the investigation of the boundary layer contribution to the total aerosol load over Thessaloniki.

\section{Instrumentation, methodologies and modelling tools}

\subsection{Site description}

Measurements of the aerosol optical depth have been conducted in Thessaloniki, a city with a population of approximately 1 million, since 1997 . The measuring station is located near the centre of the city on the roof of the Physics Department of the Aristotle University of Thessaloniki $\left(40^{\circ} 38 \mathrm{~N}, 22^{\circ} 57 \mathrm{E}, 60 \mathrm{~m}\right.$ a.s.l.). The site is facing the Aegean Sea to the south and is situated along the expected pathway through which pollution from central and Eastern Europe influences aerosol loading over the Eastern Mediterranean. Three different instruments have been used to derive the AOD. Their main characteristics and the methodologies used are presented in the following sections.

\subsection{The Brewer spectroradiometers}

The Brewer MKIII spectroradiometer is a double monochromator, which can provide spectrally resolved measurements of the global and the direct solar irradiance. Its operational spectral range is $290-365 \mathrm{~nm}$, and its spectral resolution is $0.55 \mathrm{~nm}$ at full width at half maximum (FWHM). Details on the operation and calibration procedures are given in Bais et al. (1997). A second, single monochromator
Brewer MKII spectroradiometer measures the direct spectral irradiance with similar spectral resolution at five wavelengths in the UV-B region, nominally at 306.3, 310.0, 313.5, 316.8 and $320 \mathrm{~nm}$. The absolute calibration of both instruments is maintained by scanning every month a $1000_{-} \mathrm{W}$ quartz-halogen tungsten lamp of spectral irradiance, traceable (through Optronic Laboratories Inc.) to the National Institute of Standards and Technology standards. In addition, every six months the relationship of the direct port to the global port is determined (for Brewer MKIII) using the shadowing disk technique as described in Kazadzis et al. (2005).

The retrieval of the aerosol optical depth, especially at the shorter UV-B wavelengths, is difficult and is associated with substantial uncertainties (Marenco et al., 1997), requiring accurate and precise calibration and quality control procedures. The AOD is calculated as the residual optical depth after subtracting from the total atmospheric optical depth the optical depths due to molecular scattering, and the $\mathrm{O}_{3}$ and $\mathrm{SO}_{2}$ absorption. One key issue is the absolute calibration of the direct spectral irradiance measurements. Two approaches have been proposed: The first is based on the absolute calibration of the solar spectral irradiance measured by the Brewer (Bais, 1997; Marenco et al., 1997; Meleti and Cappellani, 2000; Kazadzis 2005; Gröbner and Meleti, 2004), while the second uses the Langley extrapolation method to derive the absolute calibration of the irradiance (Jaroslawski and Krzyscin, 2000; Jaroslawski et al., 2003; Kirchhoff et al., 2001; Marenco et al., 2002; Cheymol and De Backer 2003; Groebner and Meleti, 2004). The AOD derived from both methods appears consistent with those measured independently by a multifilter rotating shadow-band radiometer (Marenco et al., 2002) and by a CIMEL Sun photometer (Jaroslawski and Krzyscin, 2000; Meleti and Cappellani, 2000). In this study, following the methodology described in Marenco et al. (1997), we used absolutely calibrated direct irradiance spectral measurements in the range $290-365 \mathrm{~nm}$ and in steps of 0.5 to retrieve the total column of the aerosol optical depth. The spectral AOD is determined by comparing the measured cloud-free spectrum of the direct irradiance with the direct irradiance at the surface which is calculated from the transfer of the high resolution extraterrestrial spectrum ATLAS 3 (Van Hoosier, 1996) through the atmosphere using the Beer's law and accounting only for molecular absorption (mainly $\mathrm{O}_{3}$ and $\mathrm{SO}_{2}$ ) and Rayleigh scattering. The Rayleigh optical depth was calculated according to Hansen and Travis (1974) and the ozone cross sections (for -44 degrees $\mathrm{C}$ of temperature) were taken from Bass and Paur (1985). According to Cheymol and DeBacker (2003), the sensitivity of the calculated AOD to the effective ozone temperature is $-0.065 \% / \mathrm{K}$ for $320.1 \mathrm{~nm}$. This means that a typical mid-latitude annual variation in the effective ozone temperature in the order of 30-35 degrees will affect the AOD calculation by $1.9-2.3 \%$. Therefore the maximum uncertainty in the AOD introduced by this factor is $\pm 1.1 \%$. The calculations are performed at the resolution of the ATLAS 
3 spectrum and the derived high-resolution irradiance at the ground is convoluted with the instrument's slit function to derive finally the optical depth. The basic method that was used to calibrate the measured direct irradiance spectra and the uncertainties of the methodology are described in Bais (1997) and in Kazadzis et al. (2005). The calibration method has been recently improved to account for polarization effects from the instrument's window (Cede et al., 2006).

Uncertainties in the AOD retrieval from Brewer spectroradiometric measurements arise either form the instrument's operation (e.g. occasions of non ideal positioning of the input optics to the sun) or from the AOD retrieval methodology (e.g. the assumption of negligible $\mathrm{NO}_{2}$ concentrations). The latter may lead to an overestimation of the calculated AOD of at most 0.005 and 0.01 , respectively at 320 and $340 \mathrm{~nm}$ for each Dobson Unit of $\mathrm{NO}_{2}$ (Arola and Koskela, 2004). The uncertainty analysis of the AOD retrieval using the MKIII Brewer showed an error on the AOD which is estimated to within 0.07 in the UV- $B$ and 0.05 in the UV- $A$ for measurements at solar zenith angles between $15^{\circ}$ and $75^{\circ}$ (Kazadzis et al., 2005). This error is the result of the propagation of errors due to the direct irradiance measurement and calibration uncertainties, the determination of the extraterrestrial spectrum, and the measurement of ozone and $\mathrm{SO}_{2}$.

A second collocated Brewer MKII spectroradiometer has been also used to derive the AOD at six wavelengths in the UV-B region, following the methodology described in (Meleti and Cappellani, 2000; Groebner and Meleti, 2004; Cheymol and De Backer, 2004). In this case the Langley extrapolation method was used to derive the extraterrestrial solar flux at the six wavelengths. The use of Langley plots to calibrate an instrument for aerosol optical depth requires extremely stable atmospheric conditions during the calibration period. Especially for calibrating the MKII Brewer at Thessaloniki in the UV region, where ozone and aerosols are important, Langley plots were used only during days with stable ozone and AOD. These days are determined using a set of strict criteria in the Langley extrapolation analysis. In should be noted that the comparison of AOD derived from the MKIII and MKII is not used for validation purposes but only for investigating the long term changes in AOD derived from two instruments with different calibration principles. The uncertainty of the AOD retrieved from the MKII Brewer results from the error in determining the extraterrestrial irradiance (Marenco et al., 2002), the total ozone column measurement (Groebner and Meleti, 2004), front window polarization effects (Cede et al., 2006) and the temperature of the ozone cross sections (Cheymol and DeBacker, 2003). The total uncertainty for the AOD determination at $320 \mathrm{~nm}$ was found 0.04 for air mass 1.4 which is the mean air mass for Thessaloniki. The AOD data used in this study by the two Brewer spectroradiometers were obtained during the period 1997-2005.

\subsection{CIMEL sunphotometer}

Since September 2005 AOD measurements at Thessaloniki have been enriched with the addition of a CIMEL sun photometer (provided by the Department of Environmental Engineering of Democritus Univ Thrace). The CIMEL is an automatic Sun-sky scanning filter radiometer allowing the measurements of the direct solar irradiance at wavelengths 340, 380, 440, 500, 670, 870, and $1020 \mathrm{~nm}$. This CIMEL instrument is part of the NASA's Aerosol Robotic Network (AERONET). NASA provides preliminary processing of the real-time data containing the daily pattern of AOD at all operational wavelengths (level 1.5 data) (Holben et al., 1998). The instrument was calibrated on June 2005 at NASA, Goddard space flight center facility.

\subsection{Backward trajectories and clustering algorithm}

Analytical backward trajectories of air masses provide information about the origin of the aerosols observed at a particular location and on the dynamical patterns governing this transport of air masses. Systematic studies based on combined backward trajectories and long term aerosol vertical profile observations have been conducted for Central European locations (Mattis et al., 2000) These studies have helped in explaining the dependence of the observed aerosol optical properties on the origin of the air masses. In our study, four-day back trajectories were computed for the days of interest (cases of cloudless skies), using the Hybrid SingleParticle Lagrangian Integrated Trajectory (HYSPLIT) model (Draxler and Hess, 1997). This model uses the meteorological data produced by the ETA Model of the National Weather Service of Spain to compute advection and dispersion of air parcels. We used HYSPLIT to generate 4-day back trajectories for air-parcels arriving over the site at Thessaloniki on 12:00 UTC at an altitude of $1500 \mathrm{~m}$ for all days with available Brewer AOD measurements. Measurements of the vertical profile of the aerosol backscatter coefficient with a LIDAR showed that the maximum aerosol loading over Thessaloniki occurs at $1500 \mathrm{~m}$ above seal level (Amiridis et al., 2005).

Then, a cluster analysis algorithm was used to categorize the computed trajectories into groups of similar properties, the so-called clusters. In this study the clustering algorithm for atmospheric trajectories recommended by Dorling et al. (1992) was used, which can be used also to determine the optimum number of clusters. For the arrival height of $1500 \mathrm{~m}$ over Thessaloniki, the optimum number of clusters was found to be five.

\subsection{Measurements of the $\mathrm{PM}_{10}$}

Since 1988 the Environmental Department of Municipality of Thessaloniki operates a network of monitoring stations measuring various atmospheric pollutants and meteorological parameters. Nowadays the network consists of 


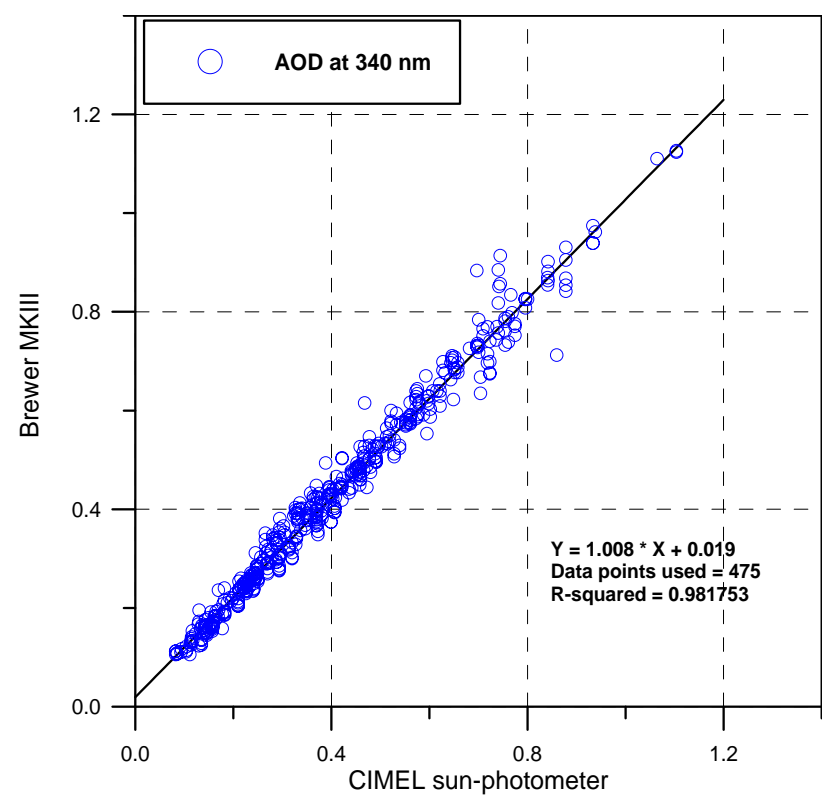

Fig. 1. Comparison of AOD at $340 \mathrm{~nm}$ retrieved by the Brewer MKIII spectroradiometer and the CIMEL Sun-photometer.

five atmospheric pollution stations and four meteorological stations. Measurements of airborne particulate matter with an aerodynamic diameter of less than or equal to a nominal 10 microns $\left(\mathrm{PM}_{10}\right)$ are conducted at all five monitoring stations. The instruments are automatic high-volume samplers that use absorption of $\beta$ radiation for the determination of the $\mathrm{PM}_{10}$ concentration. At the central station a TEOM (Tapered Element Oscillating Microbalance Method) instrument is also used, measuring simultaneously with the high volume analyzer. The correlation coefficient between the two data sets is 0.9 (Petrakakis et al., 2005). All the other stations of the municipal network are equipped only with $\beta$ radiation absorption analyzers; hence the $\mathrm{PM}_{10}$ concentrations used in the present study are from instruments of this type. The two measuring methods mentioned above are the most widely used throughout the European Networks, with the $\beta$ absorption being the prevailing one. According to this method, the suspended particulates of ambient air are separated by filtering, using a membrane, whose absorbance ability has been measured in advance. The difference in the membrane's absorbance ability before and after the filtering defines the mass of the selected particulate matter. This mass is associated with the measurement of air volume which passes through the membrane and as a result the $\mathrm{PM}_{10}$ concentration is derived. The $\mathrm{PM}_{10}$ analyzers are checked and calibrated on a regular basis to ensure the accuracy of the measurements. Two specific beta gauge tests are made to verify the influence of the Geiger counter noise on the measurement and to measure the surface density of a reference gauge. Calibration is performed each time the filter paper is changed, and every six months to check the analyzer's response.

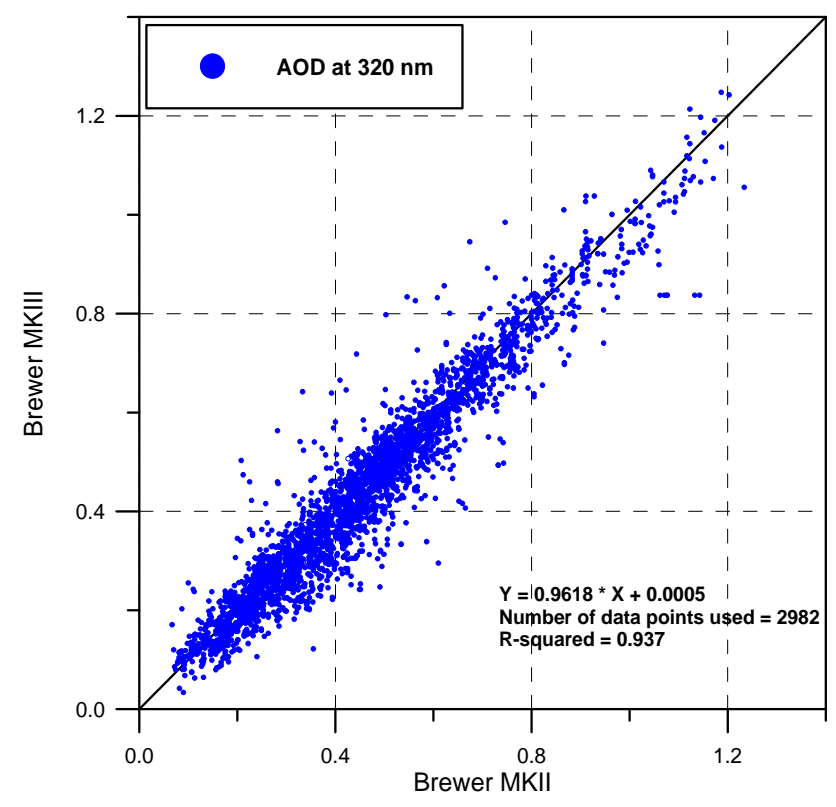

Fig. 2. Comparison of AOD at $320 \mathrm{~nm}$ retrieved by the Brewer MKIII and the Brewer MKII spectroradiometers.

\section{Aerosol optical depth comparisons}

The aerosol optical depth measurements derived with the Brewer spectroradiometer were compared: i) with standard measurements of AOD from the CIMEL sun-photometer, ii) with AOD measurements from the second Brewer spectroradiometer that uses a different methodology for retrieving the AOD.

The AOD at $340 \mathrm{~nm}$ derived from the Brewer MKIII and from the CIMEL sun-photometer were compared for a period of 6 months (October 2005-March 2006) under cloudlesssky conditions. The irradiance at $340 \mathrm{~nm}$ is practically unaffected by ozone and $\mathrm{SO}_{2}$ variations. About 500 synchronized (with a time difference of less than $10 \mathrm{~min}$ ) measurements were used for this investigation (see Fig. 1). The two datasets are highly correlated $\left(r^{2}=0.98\right)$ and have no significant offset. The mean AOD for this period was calculated to 0.403 and 0.422 respectively for the Brewer and the CIMEL. The average difference is 0.019 with a standard deviation $(1 \sigma)$ of 0.022 . One possible reason that could partly explain this difference is the difference in the field of view of the two instruments (Cimel is $1.2^{\circ}$ and for the Brewer is $\sim 2^{\circ}$ ) so the diffuse light effect for the latter should be larger. Of course, exact reasons are difficult to estimate, since different calibration and procedures for AOD retrieval are involved too.

A comparison of the AOD at $320 \mathrm{~nm}$ retrieved from the two Brewer spectroradiometers during the period 1997-2005 is shown in Fig. 2. Here we used the AOD at $320 \mathrm{~nm}$, because although this wavelength is affected by ozone, it is the longest available wavelength in the Brewer MKII measurements. About 3000 data points (with time difference of less 


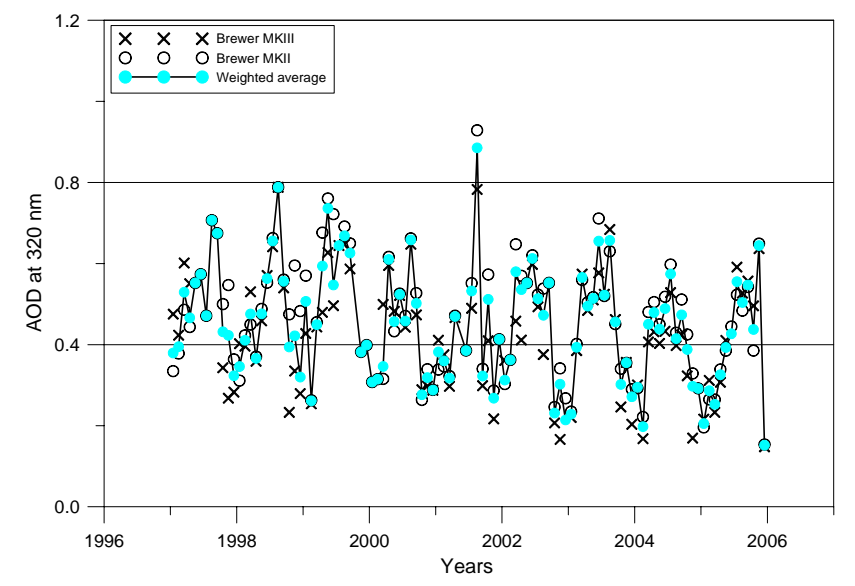

Fig. 3. Monthly mean AOD at $320 \mathrm{~nm}$ for the period 1997-2006, derived from the MKIII (crosses) and MKII (open circles) Brewer spectroradiometers. Line and full circles represent the weighted average of the two instruments.

than $10 \mathrm{~min}$ ) under cloud free skies are included in this comparison. For the selection of the cloud free days we used the methodology described in Vasaras et al. (2001), which is based on the variability of the measurements from a collocated pyranometer. The correlation between the two data sets is again high $\left(r^{2}=0.937\right)$, taking into account that the two instruments use completely different methodologies to derive the AOD. Comparison of the AOD derived by the two Brewer spectroradiometers shows that the single monochromator Brewer MKII overestimates by about 5\% the AOD. This difference could be related to the different calibration procedures and methodologies used in the two instruments for the AOD retrieval.

\section{Long term variability of aerosol optical depth}

The long term variability of the AOD at $320 \mathrm{~nm}$ at Thessaloniki is discussed in this section, using monthly mean values for the period January 1997-December 2005 from both Brewer spectroradiometers (Fig. 3). The monthly means have been calculated from daily averages of AOD, derived from all single measurements. For both instruments we have used the methodology of Vasaras et al. (2001) that helped including only data corresponding to cloudless sky cases. Only months with more than 8 days of data have been considered. Some of the gaps in the series of the MKIII Brewer are due to the relocation of the instrument to participate in experimental campaigns away from the home site.

The long term monthly mean AOD at $320 \mathrm{~nm}$ derived from the MKIII Brewer was found $0.43 \pm 0.12(1 \sigma)$, while the mean AOD from the MKII is $0.46 \pm 0.14(1 \sigma)$. The difference between monthly averages from the two instruments is partly due to the different number of days forming each monthly mean, as the two instruments have different mea-
Table 1. Mean and standard deviation of the columnar aerosol optical depth measured at Thessaloniki for different seasons during the period 1997-2005.

\begin{tabular}{ll}
\hline Season & Mean AOD at $340 \mathrm{~nm}$ and $(1 \sigma)$ \\
\hline Winter & $0.33 \pm 0.14$ \\
Autumn & $0.39 \pm 0.22$ \\
Spring & $0.43 \pm 0.21$ \\
Summer & $0.53 \pm 0.17$ \\
\hline
\end{tabular}

surement schedules. Nevertheless, the annual pattern of the AOD variability is similar for both datasets, with maximum values in the summer periods and minimum values in winter.

For Brewer MKIII, the standard deviation $(1 \sigma)$ of the daily measurements of AOD at $320 \mathrm{~nm}$ forming the monthly averages is on the average 0.12 with minimum and maximum of 0.02 and 0.21 , respectively. Similarly, for MKII the standard deviation was found to be 0.15 with minimum and maximum of 0.01 and 0.27 , respectively.

Both series of AOD show a negative change from 1997 towards 2005. A linear regression on the MKIII diseasonalized data reveals a change of $-2.9 \pm 0.92 \%,-3.8 \pm 0.93 \%$ and $-3.5 \pm 1.02 \%$ per year for 320,340 and $355 \mathrm{~nm}$, respectively. The statistical significance of this change was found better than $99 \%$ using student's t-test. For Brewer MKII the change of AOD at $320 \mathrm{~nm}$ for the same period was calculated to $-3.2 \pm 0.6 \%$ per year (with statistical significance similar to MKIII), which is similar to the one calculated from the MKIII data.

In Fig. 3 the results of a monthly mean AOD series merging the two instruments is shown. Measurements of MKII instrument were calibrated by direct comparison with the MKIII (Fig. 2), over the whole nine year period. In addition, the number of available days of each instrument (per month), have been taken into account in the calculation of the weighted average. The AOD change per year calculated from the merged data set was calculated to $2.9 \pm 0.9 \%$ for $320 \mathrm{~nm}$.

The frequency distribution of the AOD at $340 \mathrm{~nm}$ observed at Thessaloniki is shown in Fig. 4, for bins of 0.1 AOD units. Nearly $50 \%$ of the cases lie between 0.2 and 0.5 , while more than $30 \%$ of the cases show AOD values higher than 0.5 which indicates a location with high aerosol load. The seasonal characteristics of the frequency distribution of occurrence of AOD at $340 \mathrm{~nm}$ are also shown in Fig. 4. More than $50 \%$ of the cases in wintertime the AOD is lower than 0.3, while in the summertime in more than $50 \%$ of the cases the AOD is higher than 0.5. For autumn and spring the frequency distribution does not deviate more than $5 \%$ for all AOD bins from the average frequency distribution. The mean AOD at $340 \mathrm{~nm}$ and the standard deviation of the mean for the four seasons are summarized in Table 1. 


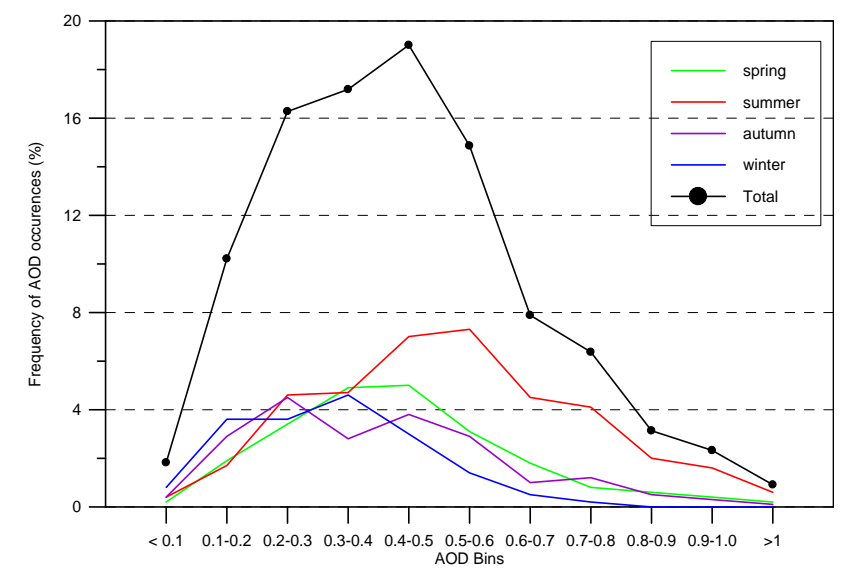

Fig. 4. Frequency distribution (in percent) of total and seasonal AOD (at $340 \mathrm{~nm}$ ) occurrences in bins of 0.1 .

The wavelength dependence of the optical depth at Thessaloniki is investigated for the period 1997-2005 using the Ångström's power law approximation:

$\tau(\lambda)=\beta * \lambda^{-\alpha}$

where $\tau(\lambda)$ is the AOD at wavelength $\lambda(\mu \mathrm{m})$ and $\alpha, \beta$ are the Ångström coefficients. The Ångström exponent, $\alpha$, was derived from an exponential regression on the spectral optical depth in the wavelength range $325-350 \mathrm{~nm}$. The spectral region below $325 \mathrm{~nm}$ was excluded from the regression in order to minimize the uncertainties introduced in the spectral AOD by possible leakage in the parameterization of the ozone effects. The average value of the Ångström coefficient, $\alpha$, for the entire dataset was estimated to $1.63 \pm 0.53$. Gerasopoulos et al. (2003) found an Ångström coefficient of $1.57 \pm 0.28$ using one year (2001) of data from a Multifilter Radiometer (MFR) at the same location. The MFR measures the global and diffuse irradiance at selected wavelengths in the visible part of the spectrum. Values of the Ångström exponent, $\alpha$, of about 1.2 to 1.4 are representative of continental aerosols, whereas for larger aerosols (dust, sea-salt) the exponent has lower values (Michalsky et al., 2001).

The long term monthly means of AOD and a derived from both Brewers are shown in Fig. 5. Both instruments reveal a clear annual pattern with a distinct maximum of AOD in the summer months (between 0.5 and 0.6 for AOD at $320 \mathrm{~nm}$ ), while in the winter period the AOD reaches a minimum of about 0.3 . As for Fig. 3, the differences in the monthly means from the two instruments are due to differences in the data points forming each mean, as a result of different measuring schedules. However, these differences are within the $1 \sigma$ uncertainty of the mean. In addition, a slight seasonality can be observed in the Ångstrom exponent, $\alpha$, monthly means. A summer maximum of 1.6 was found in July and August and a winter minimum of 1.2 in December. This is an indication of the presence of larger aerosol particles during the sum-

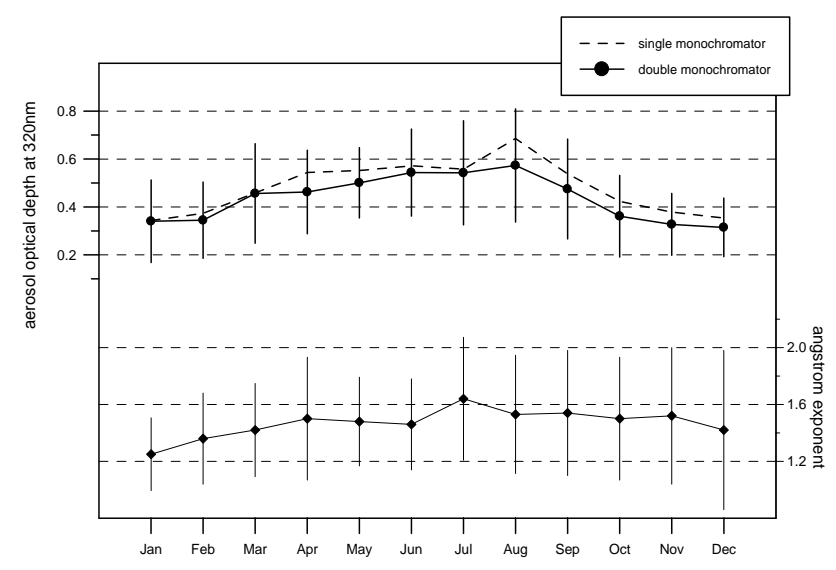

Fig. 5. (Upper panel) Monthly mean AOD at $320 \mathrm{~nm}$ and standard deviation $( \pm 1 \sigma)$ as measured by the MKIII Brewer spectroradiometer over Thessaloniki for the period 1997-2005. The dashed line corresponds to the measurements derived from the MKII Brewer. (Lower panel) Monthly mean and standard deviation of the Ångström exponent, $\alpha$, derived from Brewer MKIII data in the same period.

mer months. However, these variations are well within the $1 \sigma$ standard deviation, as shown in the lower panel of Fig. 5. The long term trend of the Ångstrom exponent alpha showed a small increase over the years but with no statistical significance and well within the standard deviation of the monthly mean values.

The observed AOD seasonality can be attributed to various processes: Enhanced evaporation and high temperatures in the summer increase the turbidity in the boundary layer and in conjunction with stagnant weather systems over the area help in the built up of the aerosols. The summer peak in the AOD is also supported by the absence of significant wet removal of aerosols and by the trans-boundary transportation of particles from eastern directions. The latter is confirmed by the consistency of the back-trajectories that are presented in the next section. During the winter months, there is significant wet deposition of aerosols, which together with the northern winds that are dominant in the area, result in cleaning of the atmosphere and thus to lower AOD values.

\section{Origin of aerosols at Thessaloniki}

The total column AOD measured in Thessaloniki can be considered as the sum of two main contributors. The aerosols that are associated from local sources and can be found in the boundary layer and aerosols in higher altitudes that are transported and reach the city from sources outside the city limits. To explain part of the observed seasonality in AOD these two contributors have been investigated. 
Table 2. Aerosol characteristics for the five clusters of back trajectories.

\begin{tabular}{lllllll}
\hline Cluster number & $\begin{array}{l}\text { Mean AOD at } \\
340 \mathrm{~nm} \\
\text { Standard devia- } \\
\text { tion) }\end{array}$ & $\begin{array}{l}\text { Ånström } \\
\text { nent, } \alpha \\
\text { Standard } \\
\text { tion) }\end{array}$ & expo- & Occurrence $(\%)$ & Winter \% & Summer \% \\
\hline 1 & $0.24(0.12)$ & $1.53(0.43)$ & 14 & 32 & 5 \\
2 & $0.46(0.21)$ & $1.56(0.40)$ & 27 & 27 & 38 \\
3 & $0.38(0.17)$ & $1.67(0.43)$ & 18 & 15 & 19 \\
4 & $0.59(0.16)$ & $1.68(0.44)$ & 15 & 12 & 21 \\
5 & $0.47(0.18)$ & $1.61(0.56)$ & 16 & 14 & 17 \\
\hline
\end{tabular}

\subsection{Origin of air masses arriving at Thessaloniki}

We used back trajectories to investigate whether the magnitude of the observed AOD is associated with the origin of the air masses traveling in high altitudes and reaching the city. Back trajectories of up to four days for air-parcels arriving at 12:00 UTC over Thessaloniki at $1500 \mathrm{~m}$ a.s.l. were generated with the HYSPLIT model and for every day with AOD measurements. These 968 trajectories were categorized in five major clusters and are shown in Fig. 6. For each cluster the so-called seed trajectories have been determined, representing the average path of the air masses.

Cluster 1 represents fast transport of air mass mainly from the Atlantic Ocean. Cluster 2 is the most common one, with air masses generally originating from Northern directions. The trajectories of cluster 3 correspond generally to westerly directions, while cluster 4 to easterly directions. Finally the 5th cluster includes mostly air masses travelling over shorter distances and, in some cases, those from the Saharan desert. Table 2 summarizes the aerosol characteristics of the five clusters, including the average and standard deviation of AOD and the Ångström exponent, $\alpha$, the frequency of occurrence of each cluster and the contribution of the winter and summer seasons. Daily means of the AOD were calculated for days that include at least 7 observations.

The data of Table 2 suggest that clusters 2, 3 and 5 contain trajectories that result in AOD close to the average AOD for all clusters (0.41), while clusters 1 and 4 correspond to the minimum and maximum AOD, respectively. Cluster 1 represents transport of masses containing very low aerosol load and measurements within this cluster can be characterized as cases with only boundary layer aerosol load and with minimum contribution from the free troposphere. From the occurrences of these cases it can be seen that they are dominant in the wintertime representing $32 \%$ of all cases, while in the summer months they are very uncommon, in the order of $5 \%$ of total cases. During these months, air masses from northwest directions reach northern Greece, and are associated with increased wind speed and atmospheric washout, and with subsidence of air from the upper troposphere.
Cluster 4 represents air masses from eastern directions which are associated with high aerosol loads over Thessaloniki. Lidar measurements (Amiridis et al., 2005) have shown that aerosols in the free troposphere transported from other regions may contribute to the total AOD by up to $50 \%$, especially in the summer months. Various studies have demonstrated that in the summer months aerosols in the Eastern Mediterranean are largely affected by biomass burning episodes from forest fires in northern coast of the Black Sea (Salisbury et al., 2003; Balis et al., 2003). Zerefos et al. (2000) reported that $70 \%$ of the SO2 column measured at Thessaloniki can be attributed to lignite combustion in power plants in Bulgaria and Romania.

The monthly mean contribution of each cluster to the total aerosol optical depth is shown in Fig. 7. Aerosol optical depths corresponding to trajectories of cluster 4 are high during all months, but mainly in the summer (summer mean $=0.64$ ) and they dominate the long term monthly means of AOD (thick black line). The mean AOD for cluster 1 is about 0.24. About one third of the cases of this cluster are found in winter, when cloudless skies are usually associated with northern winds that transport air masses with low aerosol content, confirming earlier results by Amiridis et al. (2005).

\subsection{Analysis of the $\mathrm{PM}_{10}$ measurements}

The $\mathrm{PM}_{10}$ measurements conducted by the municipality of Thessaloniki are used to investigate the tendencies of the aerosols in the lower boundary layer of Thessaloniki. Daily means were calculated for all four stations in the period 1997-2005, which were then combined to form monthly mean values of $\mathrm{PM}_{10}$.

The upper panel of Fig. 8 shows the deseasonalized 9-year long monthly means of the $\mathrm{PM}_{10}$ concentration for each station. On the same figure, the average of the monthly mean departures from all stations is also shown. A negative change is evident at all stations ranging from $-2 \%$ to $-5.6 \%$ per year, with an average of $-3.8 \pm 0.6 \%$ per year. The statistical significance of this average change was calculated to better than $99.9 \%$, based on the student's t-test. 

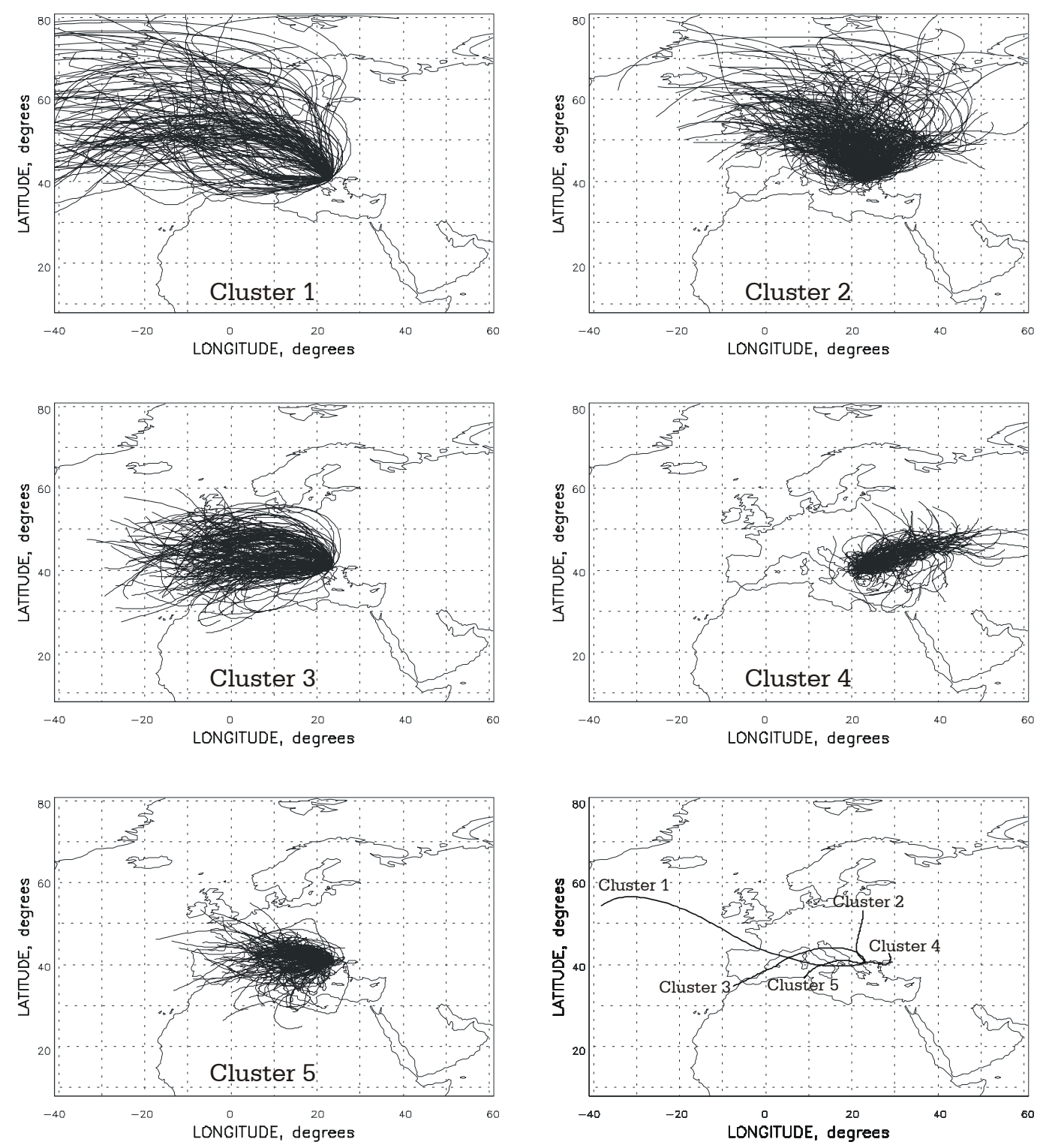

Fig. 6. Four-day back trajectories corresponding to for all AOD measurements conducted at Thessaloniki during the period 1997-2005, grouped in different clusters, representing air masses with similar characteristics and originating from similar directions. The bottom-right panel shows the seed trajectories for all clusters.

The overall change for the $\mathrm{PM}_{10}$ concentrations in Thessaloniki calculated from measurements starting in the late 1980s is negative although there are differences in the magnitude among the stations. This is more apparent for the stations influenced by traffic emissions and less for the urban ones. This remark is of high importance, since during the period 1989-2003 there has been a significant increase in the fleet of the vehicles. However, during this period in the city centre the decrease is approximately $22 \%$ for $\mathrm{PM}_{10}$ concentrations, whereas for the other primary pollutants is much larger (50\% for CO, $47 \%$ for $\mathrm{SO} 2$ and $30 \%$ for $\mathrm{NO}$ ). This development is due to a series of measures that had been taken during the 1990s concerning many aspects of the city activities (Petrakakis et al., 2005). Such measures were the usage in the industry of crude oil with low sulphur content, the improvement of fuel quality (total ban of leaded fuel), the renewal of the fleet with vehicles using anti-pollution technology, the introduction of the annual check in the exhausts control and finally measures related with the city infrastructure such as the construction and function of the ring road and extensive usage of mechanical besoms for road and pavement cleaning.

For Thessaloniki, the concentration of $\mathrm{PM}_{10}$ represents the largest part of the total aerosol load (Voutsa et al., 2002) and 


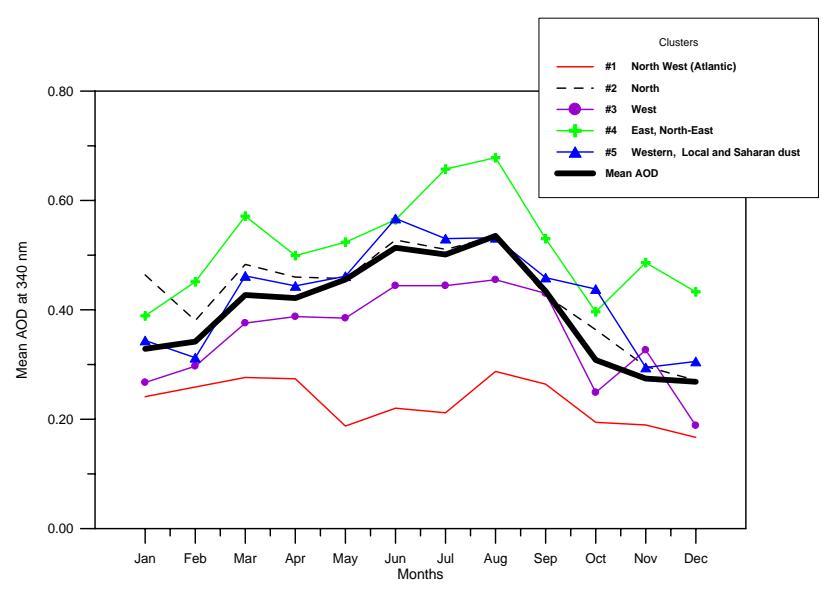

Fig. 7. Monthly mean AOD for each cluster during the period 19972005. The thick black line represents the monthly averages of AOD measured at Thessaloniki.

the columnar amount of the aerosols is dominated by those found in the first 2-3 km (e.g. Amiridis et al., 2005). Therefore it is reasonable to expect that the $\mathrm{PM}_{10}$ concentration is a major contributor to the total column of the aerosol optical depth over Thessaloniki. The long-term changes found in the $\mathrm{PM}_{10}$ concentration, agree quite well with the linear change (ranging between -2.9 and $-3.8 \%$ for different wavelengths that was calculated for the AOD as derived from MKIII measurements (see lower panel of Fig. 8).

\section{Summary and conclusions}

Nine years (1997-2005) of direct sun spectral measurements at Thessaloniki, Greece, were used for the determination of the spectral aerosol optical depth AOD in the UV-B and UVA parts of the solar spectrum, as well as of the Angström exponent.

Measurements of the AOD retrieved from two Brewer spectroradiometers and a CIMEL sun-photometer were compared showing generally good agreement. The mean absolute difference between AOD measurements in the UV$\mathrm{B}$ from the double monochromator Brewer MKIII and the single monochromator Brewer MKII is $\sim 5 \%$ (with an $R^{2}$ of 0.937 ), although the two instruments used different procedures for the their calibration and AOD retrieval. Very good agreement was found between measurements of AOD at $340 \mathrm{~nm}$ derived from Brewer MKIII and from the CIMEL (mean absolute difference $\sim 4 \%$ with $R^{2}=0.982$ ).

Long term monthly means of AOD at $340 \mathrm{~nm}$ at Thessaloniki show a seasonal variation with maximum optical depth values in the summer months $(\mathrm{AOD}=0.52$ in August), and minimum in wintertime $(\mathrm{AOD}=0.28$ in December). Another study using different instruments and techniques showed similar results for even smaller periods of data (Gerasopoulos et al., 2003).

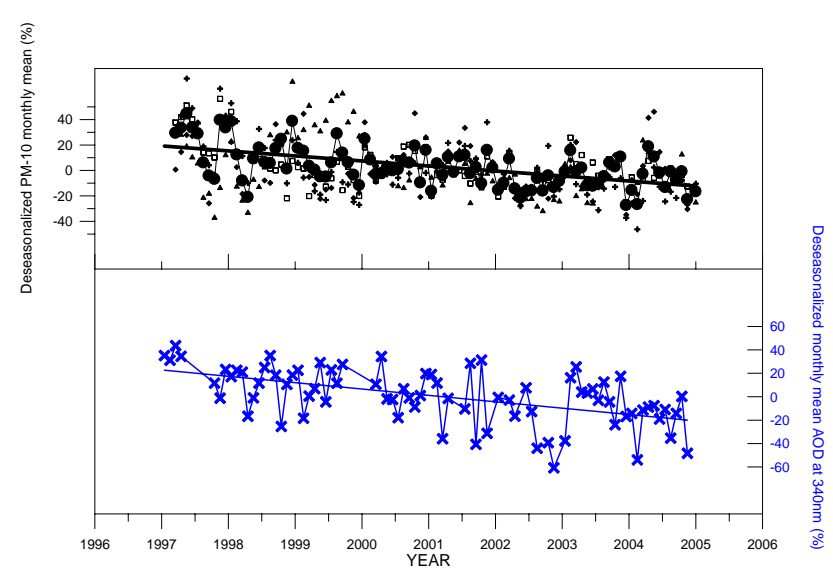

Fig. 8. Upper panel: Deseasonalized monthly mean $\mathrm{PM}_{10}$ aerosol concentration (solid circles) at Thessaloniki. Smaller symbols are monthly means at each of the four aerosol monitoring stations of the Municipality Network. Lower panel: Deseasonalized monthly mean AOD (crosses) measured at Thessaloniki with Brewer MKIII.

The analysis of the origin of aerosols at Thessaloniki showed that in addition to the boundary layer aerosol originating mainly from local sources, transport of aerosols at higher altitudes contribute to the total AOD column, especially in the summer months. Back trajectories analysis showed that the contribution of air masses coming from the North and North Eastern directions result in high aerosol loads over Thessaloniki, while minimum AOD is associated with air masses originating from the Atlantic ocean.

The AOD measurements derived from Brewer MKIII during the period 1997-2005 show a trend of about $-2.9 \%$ per year at $320 \mathrm{~nm}$ and $-3.8 \%$ per year at $340 \mathrm{~nm}$. Similar decreasing tendency has been found in the $\mathrm{PM}_{10}$ aerosol concentrations from the data of the network of the Municipality of Thessaloniki (Petrakakis et al., 2005). Both datasets suggest that the air quality in Thessaloniki is improving, compared with the situation during the 1990s, resulting in cleaning of the lower atmosphere in Thessaloniki. However, the absolute values of both optical depth and $\mathrm{PM}_{10}$ concentrations during the last decade are still high. This observed decrease in the aerosol amounts is expected to have a direct effect on the solar irradiance levels reaching the ground (Garane et al., 2005).

To conclude, the aerosols found over Thessaloniki result from different sources, comprising of a marine component, a mineral dust component (outbreaks of Saharan dust and local dust suspension) and an anthropogenic component. High aerosol optical depths may occur during the presence of either absorbing or non-absorbing particles and hence information from various instruments are necessary in order to assess properly the detailed nature and the optical properties of such a complex aerosol mixture. 
Acknowledgements. This work has been conducted partly in the framework of the projects "SCOUT-O3" funded by the European Commission, and "Environmental Impacts of Atmospheric Aerosol Particles- Pythagoras I" funded by the Greek Secretariat of Research and Technology. S. Kazadzis acknowledges the financial support of the Greek Scholarships Foundation (2005-2006, IKY).

Edited by: A. Nenes

\section{References}

Ackerman, A. S., Toon, O. B., Taylor, J. P., Johnson, D. W., Hobbs, P. V., and Ferek, R. J.: Effects of aerosols on cloud albedo: Evaluation of Twomey's parametrization of cloud susceptibility using measurements of ship tracks, J. Atmos. Sci., 57 2684-2695, 2000.

Amiridis, V., Balis, D. S., Kazadzis, S., Bais, A., Giannakaki, E., Papayannis, A., and Zerefos, C.: Four-year aerosol observations with a Raman lidar at Thessaloniki, Greece, in the framework of EARLINET, J. Geophys. Res., 110, D21203, doi:10.1029/2005JD006190, 2005.

Anderson, T. L., Charlson, R. J., Schwartz, S. E., Knutti, R., Boucher, O., Rodhe, H., and Heintzenberg, J.: Climate forcing by aerosols - A hazy picture, Science, 300, 1103-1104, 2003.

Arola, A. and Koskela, T.: On the sources of bias in aerosol optical depth retrieval in the UV range, J. Geophys. Res., D. Atmospheres, 109, D08209, doi:10.1029/2003JD004375, 2004.

Cheymol, A. and de Backer, H.: Retrieval of the aerosol optical depth in the UV-B at Uccle from Brewer ozone measurements over a long time period 1984-2002, J. Geophys. Res., D. Atmospheres, 108(D24), 4800, doi:10.1029/2003JD003758, 2003.

Bais, A. F.: Absolute spectral measurements of the direct solar ultraviolet irradiance using a Brewer spectrophotometer, Appl. Opt., 36, 5199-5204, 1997.

Balis, D. S., Amiridis, V., Zerefos, C., Gerasopoulos, E., Andreae, M., Zanis, P., Kazantzidis, A., Kazadzis, S., and Papayannis, A.: Raman lidar and sunphotometric measurements of aerosol optical properties over Thessaloniki, Greece during a biomass burning episode, Atmos. Environ., 37, 4529-4538, 2003.

Balis, D. S., Amiridis, V., Nickovic, S., Papayannis, A., and Zerefos, C.: Optical properties of Saharan dust layers as detected by a Raman lidar at Thessaloniki, Greece. Geophys. Res. Lett., 31, L13104, doi:10.1029/2004GL019881, 2004.

Bass, A. M. and Paur, R. J.: The ultraviolet cross-section of ozone: I. The measurements, in: Atmospheric Ozone, Proc. Quadrennial Ozone Symposium, edited by: Zerefos, C. S. and Ghazi, A., pp. 601-606, Reidel publ., 1985.

Boucher, O. and Anderson, T. L.: GCM assessment of the sensitivity of direct climate forcing by anthropogenic sulphate aerosols to aerosol size and chemistry, J. Geophys. Res., 100, $26117-$ $26134,1995$.

Cede, A., Kazadzis, S., Kowalewski, M., Bais, A., Kouremeti, N., Blumthaler, M., and Herman, J.: Correction of direct irradiance measurements of Brewer spectrophotometers due to the effect of internal polarization, Geophys. Res. Lett., 33, 102806, doi:10.1029/2005g1024860, 2006.

Charlson, R. J., Langner, J., Rodhe, H., Leovy, C. B., and Warren, S. G.: Perturbation of the northern hemisphere radiative balance by scattering from anthropogenic sulphate aerosols, Tellus A, 43, 152-163, 1991.

Charlson, R. J., Schwartz, S. E., Hales, J. M., Cess, R. D., Coakley, J. A., Hansen J., and Hofmann, D. J.: Climate forcing by anthropogenic aerosols, Science, 255, 423-430, 1992.

Coakley, J. A., Cess, R. D., and Yurevich, F. B.: The effect of tropospheric aerosols on the Earth's radiation budget: a parameterization for climate models, J. Atmos. Sci., 40, 116-138, 1983.

di Sarra, A., Cacciani, M., DeLuisi, J., et al.: Desert aerosol in the Mediterranean, in: Mediterranean Climate: Variability and Trends, edited by: Bolle, H.-J., Springer-Verlag, 309-315, 2003.

Dorling, S., Davies, T., and Pierce, C.: Cluster analysis: A technique for estimating the synoptic meteorological controls on air and precipitation chemistry-Method and applications, Atmos. Environ., Part A, 26, 2575-2581, 1992.

Draxler, R. R., and Hess, G. D.: Description of the HYSPLIT_4 modeling system, NOAA Tech. Memo. ERL ARL-224, 24 pp., NOAA, Silver Spring, Md, 1997.

Formenti, P., Andreae, M. O., Andreae, T. W., Galani, E., Vasaras, A., Zerefos, C., Amiridis, V., Orlovsky, L., Karnieli, A., Wendisch, M., Wex, H., Holben, B. N., Maenhaut, W., and Lelieveld, J.: Aerosol optical properties and large scale transport of air masses: Observations at a coastal and a semiarid site in the eastern Mediterranean during summer 1998, J. Geophys. Res., 106, 9807-9826, 2001.

Formenti, P., Reiner, O., Sprung, D., Andreae, M. O., Wendisch, M., Wex, H., Kindred, D., Dewey, K., Kent, J., Tzortziou, M., Vasaras, A., and Zerefos, C.: The STAAARTE-MED 1998 summer airborne measurements over the Aegean Sea: 1. Aerosol particles and trace gases, J. Geophys. Res., 107, 4450, doi:10.1029/2001JD001337, 2002.

Garane K., Bais, A. F., Tourpali, K., Meleti, C., Zerefos, C., and Kazadzis, S.: Variability of spectral UV irradiance at Thessaloniki, Greece, from 15 years measurement, Proceedings of SPIE - The International Society for Optical Engineering 5886, pp. 1$10,2005$.

Gerasopoulos, E., Andreae, M. O., Zerefos, C., Andreae, T. W., Balis, D., Formenti, P., Merlet, P., Amiridis, V., and Papastefanou, C.: Climatological aspects of aerosol optical properties in Northern Greece, Atmos. Chem. Phys., 3, 2025-2041, 2003, http://www.atmos-chem-phys.net/3/2025/2003/.

Groebner, J. and Meleti, C.: Aerosol optical depth in the UVB and visible wavelength range from Brewer spectrophotometer direct irradiance measurements: 1991-2002, J. Geophys. Res., 25(109), D09202, doi:10.1029/2003JD004409, 2004.

Hansen, J. E. and Travis, L. D.: Light scattering in planetary atmospheres, Space Sci. Rev., 16, 257-610, 1974.

Holben, B. N., Eck, T. F., Slutsker, I., et al.: AERONET - A federated instrument network and data archive for aerosol characterization, Rem. Sens. Environ., 66, 1-16, 1998.

Intergovernmental Panel on Climate Change (IPCC): Climate Change 2001: The Scientific Basis, Contribution of Working Group I to the Third Assessment of the Intergovernmental Panel on Climate Change, Cambridge Univ. Press, New York, 2001.

Jarosławski, J. and Krzyścin, J. W.: Aerosol optical depth in the UV range derived from direct sun ozone observations performed by the Brewer spectrophotometer Mark II No 64 at Belsk, Proceedings of the Quadrennial Ozone Symposium-Sapporo 2000, pp. 449-451, Sapporo, Japan, 3-8 July 2000. 
Jaroslawski, J., Krzyscin, J. W, Puchalski, S., and Sobolewski, P.: On the optical thickness in the UV range: Analysis of the groundbased data taken at Besk, Poland, J. Geophys. Res., 108(D23), 4722, doi:10.1029/2003JD003571, 2003.

Kazadzis, S., Bais, A., Kouremeti, N., Gerasopoulos, E., Garane, K., Blumthaler, M., Schallhart, B., and Cede, A.: Direct spectral measurements with a Brewer spectroradiometer: Absolute calibration and aerosol optical depth retrieval, Appl. Opt., 44(9), 1681-1690, 2005.

Kiehl, J. T. and Rodhe, H.: Modeling geographical and seasonal forcing due to aerosols, in: Aerosol Forcing of Climate, edited by: Charlson, R. J. and Heintzenberg, J., pp. 281-296, J. Wiley, New York, 1995.

Kirchhoff, V. W. J. H., Silva, A. A., Costa, C. A., Paes Leme, N., Pavão, H. G., and Zaratti, F.: UV-B optical thickness observations of the atmosphere, J. Geophys. Res., 106, 2963-2973, 2001.

Koren, I., Kaufman, Y. J., Remer, L. A., and Martins, J. V.: Measurement of the effect of Amazon smoke on inhibition of cloud formation, Science, 303(5662), 1342-1345, 2004.

Lelieveld, J., Berresheim, H., Borrmann, S., et al..: Global air pollution crossroads over the Mediterranean, Science, 298, 794-799, 2002.

Luria, M., Peleg, M., Sharf, G., Tov-Alper, D. S., Spitz, N., Ben Ami, Y., Gawii, Z., Lifschitz, B., Yitzchaki, A., and Seter, I.: Atmospheric sulfur over the east Mediterranean region, J. Geophys. Res, 101, 25 917-25 930, 1996.

Marenco, F., Di Sarra, A., and De Luisi, J.: Methodology for determining aerosol optical depth from Brewer 300-320 nm ozone measurements, Appl. Opt., 41, 1805-1814, 2002.

Marenco, F., Santacesaria, V., Bais, A. F., Balis, D., Di Sarra, A., Papayannis, A., and Zerefos, C. S.: Optical properties of tropospheric aerosols determined by lidar and spectrophotometric measurements (PAUR campaign), Appl. Opt., 36, 6875-6886, 1997.

Mattis, I., Jaenisch, V., Muller, D., Franke, K., and Ansmann, A.: Classification of particle extinction profiles derived within the framework of the German lidar network by the use of cluster analysis of backtrajectories, in: Lidar Remote Sensing of the Atmosphere, edited by: Dabas, A., Loth, C., and Pelon, J., pp. 211214, Ed. Ecole Polytech., Palaiseau, France, 2000.

Meleti, C. and Cappellani, F.: Measurements of aerosol optical depth at Ispra: Analysis of the correlation with UV-B, UV-A, and total solar irradiance, J. Geophys. Res., 105, 4971-4978, 2000.

Michalsky, J. J., Schlemmer, J. A., Berkheiser, W. E., Berndt, J. L., Harrison, L. C., Laulainen, N. S., Larson, N. R., and Barnard, J. C.: Multiyear measurements of aerosol optical depth in the Atmospheric Radiation Measurement and Quantitative Links programs, J. Geophys. Res., 106, 12 099-12 107, 2001.

Mihalopoulos, N., Stephanou, E., Kanakidou, M., Pilitsidis, S., and Bousquet, P.: Tropospheric aerosol ionic composition in the eastern Mediterranean region, Tellus B, 49, 314-326, 1997.
Moulin, C., Lambert, C. E., Dulac, F., and Dayan, U.: Control of atmospheric export of dust from North Africa by the North Atlantic oscillation, Nature, 387, 691-694, 1997.

Papayannis, A., Balis, D., Bais, A., van der Bergh, H., Calpini, B., Durieux, E., Fiorani, L., Jaquet, L., Ziomas, I., and Zerefos, C. S.: The role of urban and suburban aerosols on solar UV radiation over Athens, Greece, Atmos. Environ, 32, 2193-2201, 1998.

Papayannis, A., Balis, D., Amiridis, V., et al.: Measurements of Saharan dust aerosols over the eastern Mediterranean using elastic backscatter-Raman lidar, spectrophotometric and satellite observations in the frame of the EARLINET project, Atmos. Chem. Phys., 5, 2065-2079, 2005, http://www.atmos-chem-phys.net/5/2065/2005/.

Petrakakis, M., Kelesis, A., Tzoumaka, P., Tsougas, M., Tzourelis, G., and Zoumakis, N.: Long term variation of the $\mathrm{PM}_{10}$ concentration levels in Thessaloniki, HELLECO 05, O-A72, Athens, 2005.

Pinker, R. T., Ferrare, R. A., Karnieli, A., Aro, T. O., Kaufman, Y. J., and Zangvil, A.: Aerosol optical depths in a semiarid region, J. Geophys. Res., 102, 11 123-11 137, 1997.

Ramanathan, V., Crutzen, P. J., Kiehl, J. T., and Rosenfeld, D.: Aerosols,climate, and the hydrological cycle, Science, 294, 2119-2124, 2001.

Rosenfeld, D. and Lensky, I. M.: Satellite-based insights into precipitation formation processes in continental and maritime convective clouds, Bull. Am. Meteorol. Soc., 79, 2457-2476, 1998.

Salisbury, G., Williams, J., Holzinger, R., Gros, V., Mihalopoulos, N., Vrekoussis, M., Sarda-Estève, R., Berresheim, H., von Kuhlmann, R., Lawrence, M., and Lelieveld, J.: Ground-based PTR-MS measurements of reactive organic compounds during the MINOS campaign in Crete, July-August 2001, Atmos. Chem. Phys., 3, 925-940, 2003, http://www.atmos-chem-phys.net/3/925/2003/.

Twomey, S.: The influence of pollution on the shortwave albedo of clouds, J. Atmos. Sci., 34, 1149-1152, 1977.

Van Hoosier, M. E.: The Atlas-3 solar spectrum, available via anonymous ftp (ftp://susim.nrl.navy.mil), 1996.

Vasaras, A., Bais, A. F., Feister, U., and Zerefos, C. S.: Comparison of two methods for cloud flagging of spectral UV measurements, Atmos. Res., 57/1, 31-42, 2001.

Voutsa, D., Samara, C., Kouimtzis, Th., and Ochsenkuhn, K.: Elemental composition of airborne particulate matter in the multiimpacted urban area of Thessaloniki, Greece, Atmos. Environ., 36, 4453-4462, 2002

Yu, H., Liu, S. C., and Dickinson, R. E.: Radiative effects of aerosols on the evolution of the atmospheric boundary layer, J. Geophys. Res., 107(D12), 4142, doi:10.1029/2001JD000754, 2002.

Zerefos, C. S., Ganev, K., Kourtidis, K., Tzortziou, M., Vasaras, A., and Syrakov, E.: On the origin of SO2 above Northern Greece, Geophys. Res. Lett., 27, 365-368, 2000. 